\title{
From Hernádszentandrás to BioSzentandrás
}

\section{An Example of a Sustainable Bio-farm in Hungary}

\author{
Anikó Báti \\ Senior research fellow, Hungarian Academy of Sciences, Research Centre for the Humanities, \\ Institute of Ethnology
}

\begin{abstract}
Sustainable agriculture is the re-production of resources, which has a positive impact on the natural environment, assists in the survival of rural communities, and improves the quality of life through food production. The job opportunities can also positively influence the population retention of the communities. The study seeks to answer why a farming community in a traditionally agricultural area may have to re-learn the foundations of crop production on a social agricultural farm created by the local government. In this case study based on my fieldwork, I present the operation of an organic farm established with the help of external resources and specialists as a sustainable agricultural model, its effect on community life, and briefly referring to food culture and lifestyle changes that occurred in Hungary in the second half of the $20^{\text {th }}$ century.
\end{abstract}

Keywords: social agricultural project, rural community, local governance, sustainable rural development, food culture

In the $21^{\text {st }}$ century, sustainability has become the keyword for production and consumption systems responding to global challenges, such as the depletion of natural resources, environmental pollution, famine, etc., ${ }^{1}$ which has been present in the Hungarian government's rural development concepts since accession to the European Union. The main objective is to bring about harmony between farming, consumption, and the environment. Sustainable agriculture means the re-production of resources through sound management, which has a positive impact on the natural environment and biodiversity as well, assists in the survival of rural communities in multiple ways, and improves the quality of life through food production. It combines technological innovations with the knowledge of traditional husbandry. In addition to the ecological

\footnotetext{
${ }^{1}$ Sustainability as a term in the 1981 book by Lester R. Brown, head of the Worldwatch Institute, Building a Sustainable Society. According to his theory, in a sustainable society, development needs to be in harmony with the needs of society, the growth of the population, and the utilization of natural resources, while also reducing harmful environmental impacts (BROwn 1981).
} 
benefits, however, the impact on society is also significant: with the creation of job opportunities, the population retention of communities can be positively influenced (CSETE - LÁng 2005:9-10; Csurgó - MegYesi 2015).

In Hungarian agriculture, one of the long-term viable solutions in the search for a way out that started in the 1980s and intensified after the regime change could be a move toward a sustainable economy. Sustainability affects not only agriculture; it includes improving the living conditions of the community, improving its social situation, and a rational use of resources. An important condition of success, however, is the broad acceptance of basic principles such as conscious consumer habits, adapting the structure of production to local conditions, and a background of long-term economic policy and necessary financial resources. Problems need to be addressed at global, regional and local levels.

This study presents a successful example, the village of Hernádszentandrás in northeastern Hungary, and the organic farm created there (Hernádszentandrás 2016). In the case study, I look at the operation of an organic farm that was created through the involvement of external resources and specialists as a sustainable agricultural model, on its effect on community life, and I briefly refer to food culture and lifestyle changes.

Food production, which at least partially contributes to self-sufficiency, had to be re-learned and, along with innovations that aid progress, the foundations of the marketoriented farmstead were created from this starting point. The purpose of establishing the organic farm was to provide the population with low-cost, high-quality food, as well as provide jobs. The available resources (land, manpower) have been put in the service of sustainable development (Bá́I 2017).

The basis for the study was my fieldwork: in May-June 2016, I conducted semistructured interviews with the mayor and program participants about their work and their eating habits. I was able to observe the daily operation of the organic farm. Through casual conversations, I was able to form a picture of the villagers' assessment of it. The articles published in the media about them were also used as sources to learn about their work.

\section{HERNÁDSZENTANDRÁS IN THE RECENT PAST}

Most of Hungary's territory is well-suited for agricultural cultivation; this is especially so in Hernádszentandrás and its surrounding areas, where both high-quality soil and irrigation water are available (ÜvEGES 2012). For centuries, farming was the basis of livelihood for a broad layer of society. The political, economic and social changes of the second half of the $20^{\text {th }}$ century ${ }^{2}$ changed this situation. After 1948, industrial development became the main guideline of national economic policy, for which the financial resources were siphoned from agriculture. Land ownership was abolished, collectivized. Many abandoned agriculture at that time, changed their way of life, started working in cities, industries, in the service sector. ${ }^{3}$ The number of people working in agriculture declined steadily. As part of the national process, it was a turning point in the history of

\footnotetext{
${ }^{2}$ For the history of Hungary, see: Romsics 2016; for the food culture, see: KIsBán 1995.

${ }^{3}$ For the changing rural society, see: HANN 1980, 1983:69-92; Lovas Kiss 2002, 2013; SÁrKáNY 2005a:148-157; VALUCH 2005:135-159.
} 
Hernádszentandrás as well. Families making a living through farming sought to have their children educated, and these young people did not return as workers. About $10 \%$ of the population of the village was employed in the industry, commuting between their place of residence and their workplace daily or weekly, but the majority worked in the agricultural cooperative or its side branch, the light industry. Women's employment has also become common practice, which has fundamentally transformed the organization of households. Hernádszentandrás, like other villages in the region, slowly lost part of its population, ageing gradually.

The prestige of peasant life diminished. Traditional peasant society began to decay: the knowledge and skills required for independent farming, the value system, the forms of behavior, the earlier norms, family, kinship and neighborly collaborations gradually lost their significance and have not been passed on to the next generations.

The basis of large-scale agriculture replacing family farms from 1960 was mechanization, modernization, and the use of chemicals. Workers were wage-earners. Experts with skilled training and college education became increasingly important in the management of work. However, in addition to large-scale agriculture, a system of backyard, small-scale farms also emerged in the 1970s. For this, the land was leased from the agricultural cooperative. Although backyard farms were primarily used to provide families with self-sufficiency, the produced goods were an important additional income and material source in the 1970s and 1980s. It allowed them to buy prestige goods - though not land, like their ancestors did, but consumer goods, electric machines, cars, new houses.

After 1990, following the political regime change, another major restructuring of ownership took place in agriculture in line with the market economy framework. Land became a real private property once again. The state compensated the former owners with securities corresponding to the size of their holdings, which they could use for land acquisition. Agricultural cooperatives were dissolved, many lost their jobs. The backyard farm system also ceased to exist. Because of the structural transformation of agriculture, production fell sharply, by almost $50 \%$ in the $1990 \mathrm{~s}^{4}$

However, only a few returned to the earlier forms of agriculture as independent farmers; most villagers faced a crisis. Many family farms were unable to rebuild because they did not have the necessary financial capital. The small parcels that could be reclaimed could not be cultivated in modern and economic ways. The knowledge required for independent farming has been lost or outdated in recent decades. Only those were able to build a viable farmstead that had sufficient expertise, financial and contact capital to buy cheap land and machinery for cultivating. Because of this, many do not cultivate their lands themselves today but have them cultivated by tenants. Only a narrow layer of small-scale farmers emerged, but their survival is still uncertain. Their numbers have declined steadily in recent years, both in the region and across the country.

\footnotetext{
${ }^{4} 1.4$ million households were engaged in agricultural production in 1991. The number of these declined to 618,000 by 2007 , and to 482,000 by 2013 . Half of the farms produced products only for self-consumption, and an additional $32 \%$ sold beyond their own consumption. See more: AszTalos MORELL 2015.
} 
After 1990, industrial production was also in crisis - a significant part of the factories was closed down in the surrounding big cities. ${ }^{5}$ The commuting population of the village returned as unemployed. At the same time, local industrial production units - side branches of the cooperative farms - which mostly employed female workers, such as sewing workshops, also ceased to exist, further increasing the number of people struggling to make a living. Thus, by 2000 , a significant portion of the population of Hernádszentandrás - most of them under-educated - no longer wanted to make a living in agriculture but were unable to find a job elsewhere.

\section{HERNÁDSZENTANDRÁS TODAY}

The population size of Hernádszentandrás - like other settlements in the micro-region of the Encs District - has been under 1000 both in the past and in the present; currently there are 445 inhabitants. $70-80 \%$ of active earners (about 100 people) are unemployed today; the problem is similar in the wider community. The proportion of Roma population before 1990 was $5-10 \%$, now this figure has increased to $40 \%$.

From the second half of the $20^{\text {th }}$ century, there was a significant population exchange: the children of the former farmers moved to the city, but the houses left behind were occupied by new, mostly Roma families from the surrounding villages, who represented a partially different lifestyle even compared to the Roma already living here, such as not tending the gardens around their houses. Today, the families that have inhabited the village for generations and could revive the value system of traditional peasant farming are in the minority. Poverty has affected both Roma and non-Roma families. By the 2000s, there was neither financial nor intellectual potential left in the village that would have initiated or encouraged a shift from the low point and towards integration into the market economy.

From the 2000s, the fate of the village became uncertain not only because of an unemployed, increasingly aging population, but also because of the unpredictable economic policies of changing governments, which had an adverse impact on agriculture. These made the survival of small villages almost impossible. The problems of livelihood have to this day not been resolved by rural development policy.

"The biggest crime of the social policy of the last 20-25 years is that we talk about poverty, but basically self-reliance has fallen completely into disuse. 'Do it for yourself, for your own advancement.' Jobs are not created by the Good Lord. Only if many organic processes are built upon each other can it become sustainable. The poor receive almost as much aid as those who work $8-10$ hours, and they use it all up. It does not encourage them to cultivate their gardens so they might spend less. (...) I find that the villagers got too comfortable, which played a role in the situation being what it is today. It is not very fashionable to work, to tend the land. Young people say, they sure won't work the land. Basically, they have an aversion to weeding. That's a lowly job. (...) You have to make it fashionable, give it some marketing to promote a good cause: to address the young generations. They must be involved in a thousand ways in the world

\footnotetext{
${ }^{5}$ See more: SÁRKÁNY 2005b:143-151; SÁRKÁNY - HANN 2003:117-141.
} 
of tastes, plants, animals, and agriculture; that will bring them back to earth. It can provide a very important pulse, function for these small communities. This is the way out. Most small settlements with agricultural value need to build the future on this. By simultaneously carrying out all activities that are organically related to the community, development, job creation. (...) Without investments, villages will not find themselves." (Mayor of Hernádszentandrás, interviewed by Anikó Báti, 2016.)

Government measures, however, occasionally triggered erosion and negative processes, for example, by consolidating primary schools in small settlements. In Hernádszentandrás, the school was closed in 1994, and children have been taking public transport to attend school in the neighboring village. Furthermore, there is a lack of a local kindergarten, medical care, pharmacy, post office, library. The Reformed Church was the only cohesive force in the village in the early 2000s. There were no civil organizations or entrepreneurs to initiate innovation.

As the first step towards renewal, between 2002 and 2004, it was necessary to mold the disintegrating population of Hernádszentandrás into a community: a youth circle, sports club and communal village festival were organized to revive their traditions. Year after year, a growing number of community festivals and events have been featured in the program, and today their number has reached 25. Among these are the Hernád Festival, which is a multi-day event, where local dishes and specialties, for example, symbolize togetherness. In 2005, the village's past and roots were compiled in a monograph (ÜvEGES 2012). A foundation was created, which was joined by even those who moved out of the village earlier, in order to support community development with their knowledge, contact networks, and financially. They set up a scholarship to assist young people, established a Sure Start House, a special nursery-kindergarten and study hall which actively involves parents, and an after-school day-care center where children can learn foreign languages and music alongside their daily homework preparation. These initiatives had a very positively reception, they were a good starting point for selforganizing, but their social impact (putting a halt to migration and population decline) has not yet been able to produce measurable results in the short time since inception.

The task of reorganizing the village, the establishment of a market-oriented agricultural enterprise without a precedence was taken on by the local administration, ${ }^{6}$ the local government and its young leader, the mayor. The young man in his thirties studied political science at the university and saw a professional challenge in applying his knowledge to "rejuvenating" his home village. He has been involved in the operation of the local government since 2002 - he also played a significant role in the establishment of the abovementioned civil society - and was elected as mayor in 2006. He and his family - who have lived here for a long time, have done significant farming in the past, and now contribute to village life with their education and knowledge-are the drivers/key people in its development. To fulfill his dream, to become a local leader accepted by the community, beyond the family roots, the mayor tried to invigorate community life, to personally participate in everything, so, for example, he also proved to the village's elderly women that despite being a man, he was able to prepare his personal favorite dishes, including the local specialties.

\footnotetext{
${ }^{6}$ For social agricultural projects and public work organized by municipalities and civil societies in the region, see: AszTAlos Morell 2015.
} 


\section{ORGANIZATION AND OPERATION OF THE BIO-FARM}

The most widespread tool of local economic development (KABAI - NÉMETH 2012) was also used in Hernádszentandrás: ${ }^{7}$ the aim was the production and sale of local products and organic vegetables (AGóRA 2016; BioszENTANDRÁs 2016). In 2007, the starting point for the development of the bio-farm program was the availability of high-quality soil and free manpower. In addition to its administrative tasks, the local government sought to create jobs in an entrepreneurial capacity. ${ }^{8}$ Based on their own resources, they applied for external financial resources to commence a sustainable development in the village's economic life. It was designed to allow the organic farm to become independent of external aid over time, to operate on a market basis, and to become independent of the governance of the local government as well.

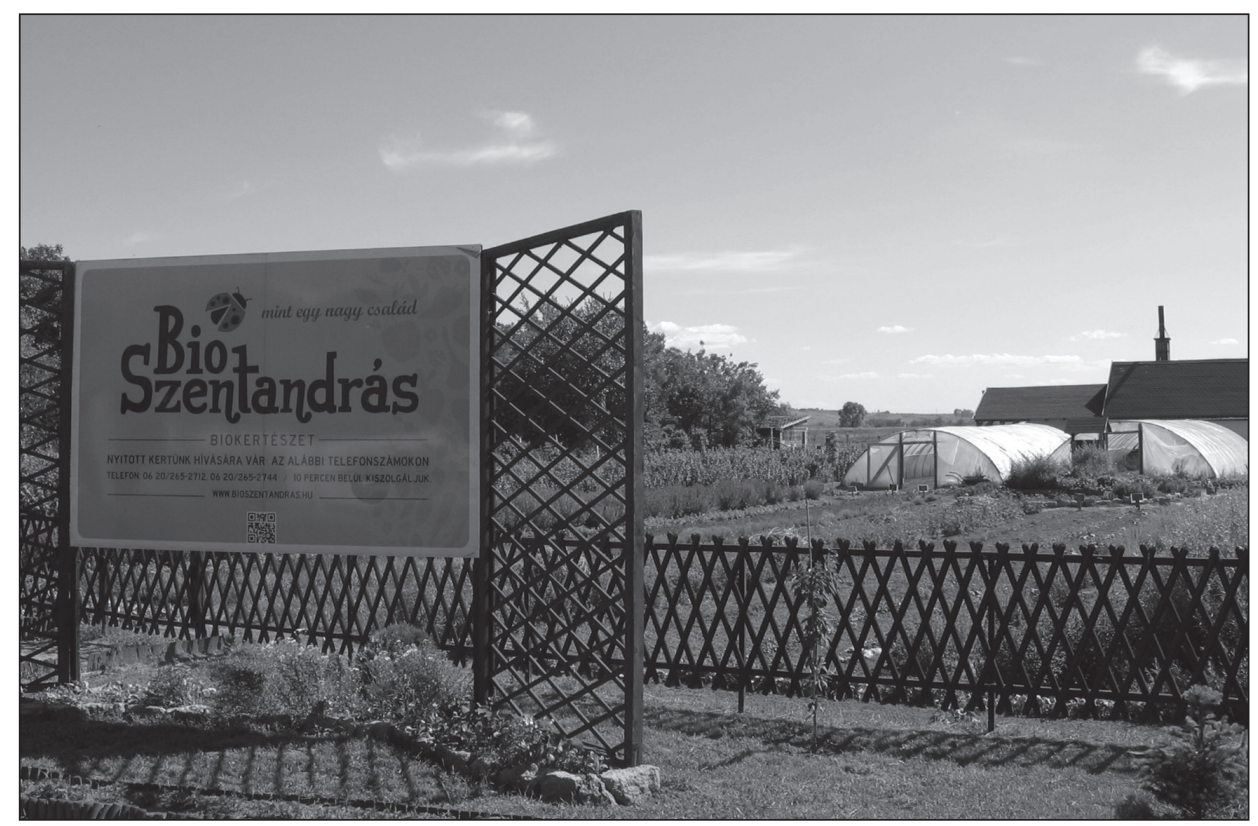

Figure 1. The gate of the Hernádszentandrás/BioSzentandrás bio-farm. With the motto: "Like a big family". Hernádszentandrás, Hungary, 2016. (Photo by Anikó Báti)

\footnotetext{
${ }^{7}$ Like in Hernádszentandrás, the complex plans for landscapes and villages like Markóc, Rozsály, Túrkeve, Tunyogmatolcs and Panyola are conceived and executed by local governments, mayors, in other cases NGOs, associations, or foundations. In Göncruszka, for example, the church community's apiary generated enough income to set up a school, augmenting human, economic, natural and social resources at the same time. KAJNER - LÁNYI 2013:16.

${ }^{8}$ Farmsteads relying on local resources and initiated by local governments developed in a variety of structures using similar concepts. Fundamentally, their goals were the same: to provide work and income, inexpensive, high-quality food for those who were permanently in a disadvantaged position. Because of grants and organizational frameworks, today there is quite a variety of praxes in operation. As a result, terminology in sociological and economic literature is not unified for these farmsteads. For an overview, see: KABAI - NÉMETH 2012.
} 
They received a grant from the European Union to launch the project. December 2010 saw the establishment of the bio-farm, and the organization of the workforce and professional training began. The location of the forming, planned farm within the flood protection ring - which, after its construction, redefined the previous image of the landscape as many of the previously cultivated areas, vineyards and meadows remained outside of it - was designated in the inner part of the village. The land used was only 6000 $\mathrm{m}^{2}$ at the start, primarily owned or rented by the local government. The program provided the participants with the raw materials, equipment and tools needed to grow the plants.

In the first year, they grew 23 kinds of garden vegetables and greenhouse plants in three plastic tunnels. Most of the produce grown was given to the workers, in proportion to their work, and only a small proportion made it to buyers. In 2012, according to an agreement with the employees, $70 \%$ was intended for sale on the market, while the remaining $30 \%$ continued to be given to workers as in-kind contribution. Since then the organic farm has gradually evolved every year. Upgrades were done by means of additional grants, and the sales revenue was also fully reinvested in the project, from which they financed the purchase of various tools, seeds, market research and other services, as well as infrastructure development. ${ }^{9}$ In 2012 they grew vegetables on 12,000 $\mathrm{m}^{2}$, in 2016 on as much as $25,000 \mathrm{~m}^{2}$, as well as 500 bushes of berries (jostaberry [Ribes nidrigolaria], black currant [Ribes nigrum], blackberry [Rubus subg. Rubus], 30 types of herbs, and lavender on $2,000 \mathrm{~m}^{2}$. In addition to the open-field cultivation, work is going on all year round in 9 plastic tunnels and a $150 \mathrm{~m}^{2}$ heated greenhouse. During the summer, irrigation is solved by means of a drip system covering the entire garden. In 2015, fruit trees were planted on another 1-hectare area. With the help of experts, cultivars were chosen to preserve the old gene pool typical of the landscape.

In the construction of the organic farm, they received professional advice from Matthew Hayes, an English agricultural engineer working in Hungary. During the professional training, the basics of organic gardening were acquired through the curriculum of the Szent István University of Agricultural Sciences in Gödöllö. An agricultural engineer living in a nearby town took the lead both in the preparations and the daily work of the garden. From these, the participants of the program learned the basics of chemical-free farming in several courses. They also received professional help in production control and plant cultivar selection from the Ecological and Agricultural Research Institute for Practical Research and Development of Organic Farming. Their wide-ranging network of contacts includes even the Hungarian affiliate of Greenpeace, who also became consultants for the project.

\footnotetext{
${ }^{9}$ The secret of the success of the program is the efficient and tireless financial coordination. The sums received from grant applications are many times the budget the state grants for the operation of the local government. (On the revenue side of the municipality, HUF 21 million, while expenditures are HUF 44 million. [In 2016, $1 €=315$ HUF.] "And here everything is on the minimum. Even the mayor's salary is 149,000 HUF gross", says the mayor.) The farm was built from a combination of four EU grants. The success in finding grant opportunities is evidenced, for example, by the fact that in 2015 the project received HUF 316 million in funding. These sums were spent solely on development, while for employment they used the public works program between 2012 and 2015. Nonetheless, there are constantly about 6-8 people who are involved as volunteers. However, the 3-year public works program was cancelled by 2016, so only the farm's own revenue can be used for this purpose.
} 


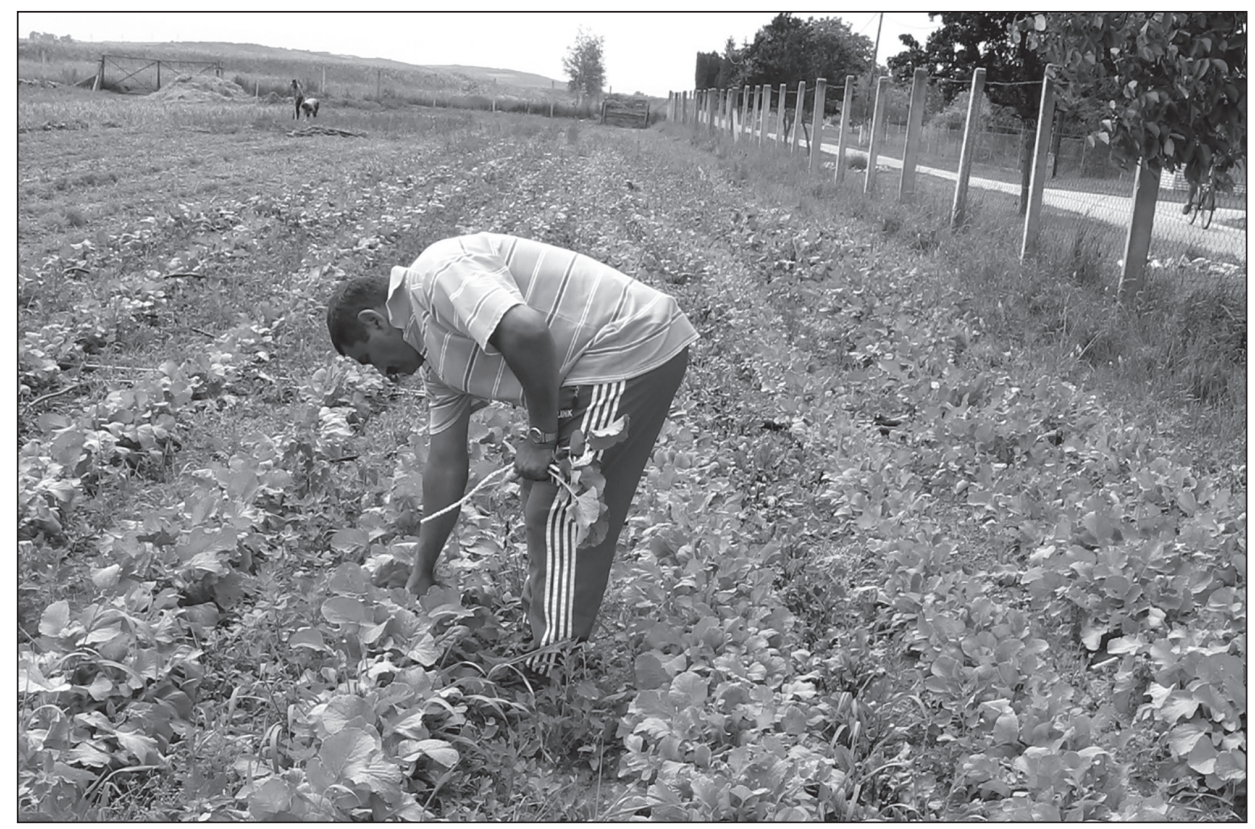

Figure 2. The treasures of the bio-farm. Hernádszentandrás, Hungary, 2016. (Photo by Anikó Báti)

The program was primarily developed for the disadvantaged, under-educated and permanently unemployed, but anyone could join. When the bio-farm was launched, ${ }^{10}$ nearly 30 of the villagers joined voluntarily, and even some from the surrounding settlements. The composition of the group was heterogeneous in terms of age (16 to 72 years of age), social status and ethnic affiliation. Those who joined assumed the burden of working in the garden for the first few years without pay, in their own free time. They got acquainted with new plants and the basics of organic gardening in weekend seminars. ${ }^{11}$ Raising awareness was key: some had already cultivated their backyard garden, but there were many people who had just started gardening, which was also a prerequisite for participating in the program, striving for organic farming there as well, mostly by reviving traditional peasant knowledge of farming.

"Even the profession is divided on this issue [i.e., how much of organic horticulture is built on traditional peasant farming knowledge]. Devotees of this new wave of organic frenzy deny that it has anything to do with peasant culture. I see that $90 \%$ of it is the carrying on or re-learning of peasant knowledge. And 10 to $15 \%$ is new knowledge, (...) for example, defensive mechanisms

\footnotetext{
${ }^{10}$ In Hernádszentandrás, the terms bio-garden and formerly model garden were used to describe the organic farm. The name 'garden' is very fitting - as I use it in the study - because, on the one hand, it refers to the small size of the cultivated parcel, and on the other, to its location within the boundaries of the village, although in the literature the currently accepted terminology is eco- or organic farm.

${ }^{11}$ Biocultivation means chemical-free production, using only natural substances for pest control: the juice of nettle, horsetail, and comfrey, or cow's milk; or, for example, by planting plants in a way that they would eliminate each other's pests.
} 
that our ancestors may not have known. It is a great challenge in itself to re-learn what was lost. (...) We also want to make gardening fashionable, and we can use modern tools (such as the Internet) as well. Obviously, there is an exaggerated version of this, where every urbanite that has never seen soil is running around in pimped-out rubber boots. But let them - I'd rather they buy rubber boots than not have rubber boots at all. So health-conscious agriculture, production and food production is becoming fashionable." (Mayor, interviewed by Anikó Báti, 2016.)

Today, there are altogether twenty employees in each sector: in production, processing and sales. The bio-farm provided an income supplement to the workers receiving unemployment benefits from the state: in the early years, they just received a share of the produced goods for their own kitchens, but now there is so much revenue that they are able to pay more and more workers an annual, fixed salary. In the future, this trend will grow stronger because, based on market fundamentals, in addition to agricultural production, their crops can now be processed and these products can also be sold throughout the year.

Those who did not join the initiative may have thought that the enterprise was inherently doomed to fail. Although, seeing the present success, they may be jealous of the permanent employment opportunity of the workers throughout the year. "They are envious of all the praise we receive", one of the employees said proudly. In the village, there is a mixed opinion of the bio-farm. Some people appreciate that they were able to come together and boost the life of the village with it. There are, however, those who look down on it and do not understand the whole thing: "My garden is organic, too, I do not use a pesticide because it is expensive, but it does not have as many weeds as they do", said a village woman in whose eyes - as she is not aware of the principles of bio-farming - the weeds between the rows of cultivated plants are not ground cover but a pest. It is very significant that the common goal, the successes, and the positive feedback have all had a constructive impact on both the participants of the program and the wider community, but at the same time doubts, failures, and conflicts that arise from the different work culture have also regularly emerged. These situations were usually solved by the mayor on a daily basis.

In addition to the managerial work of the mayor (seeking financial resources, coordinating the work, presenting the results) and the chief horticulturists, the key member of the project is the sales manager. Through her training and professional experience, she is also familiar with product development, sales, customer relations and employee relations. The key to their common success is that they built their own brand very consciously, which features the name of the village, and thus Hernádszentandrás became BioSzentandrás. Their motto is, "Like a big family". They continuously conduct market research, map the demands of custom buyers and restaurants, adjusting the annual planting schedule of the farm to them. These requirements are a big challenge for the farm. This is far from the level that a peasant farm or a social farm could easily assume. For example, the sales manager has to know two weeks in advance what and when will be ready in the garden so that the ordering restaurants could adjust their menus accordingly.

The range of products being sold is constantly expanding, incorporating employees' ideas and their own knowledge, beyond the advice of professionals. For example, one of the Roma workers can make wicker baskets, an activity that is a family tradition for him. His idea that their products be offered in these baskets at the fairs and that the baskets 
themselves be sold as handicrafts was a great success. Based on the idea of a woman who used to be a seamstress, they now also produce small souvenirs stuffed with lavender, thus enhancing the BioSzentandrás brand.

The center of product sales is the building whose name is remarkably "All that", i.e., all that is related to sales. Vegetables ordered by customers and collected from the garden are carefully picked, weighed and wrapped here, because only the best-quality goods are sold. Since the summer of 2015, the storage of the vegetables that are otherwise sellable for 24 hours has been aided by a cold storage. The slightly defective, rejected vegetables from the garden end up as waste and are placed in the compost pile in fairly large quantities. There is no real solution yet for utilizing goods that are less than perfect. In this respect, peasant farming represented a completely different view, where nothing was wasted. However, the sales manager is looking for solutions, with restaurants and buyers who in developing new recipes might use the less standard, previously wasted goods, such as a larger-leaved spinach or lettuce that cannot be sold.

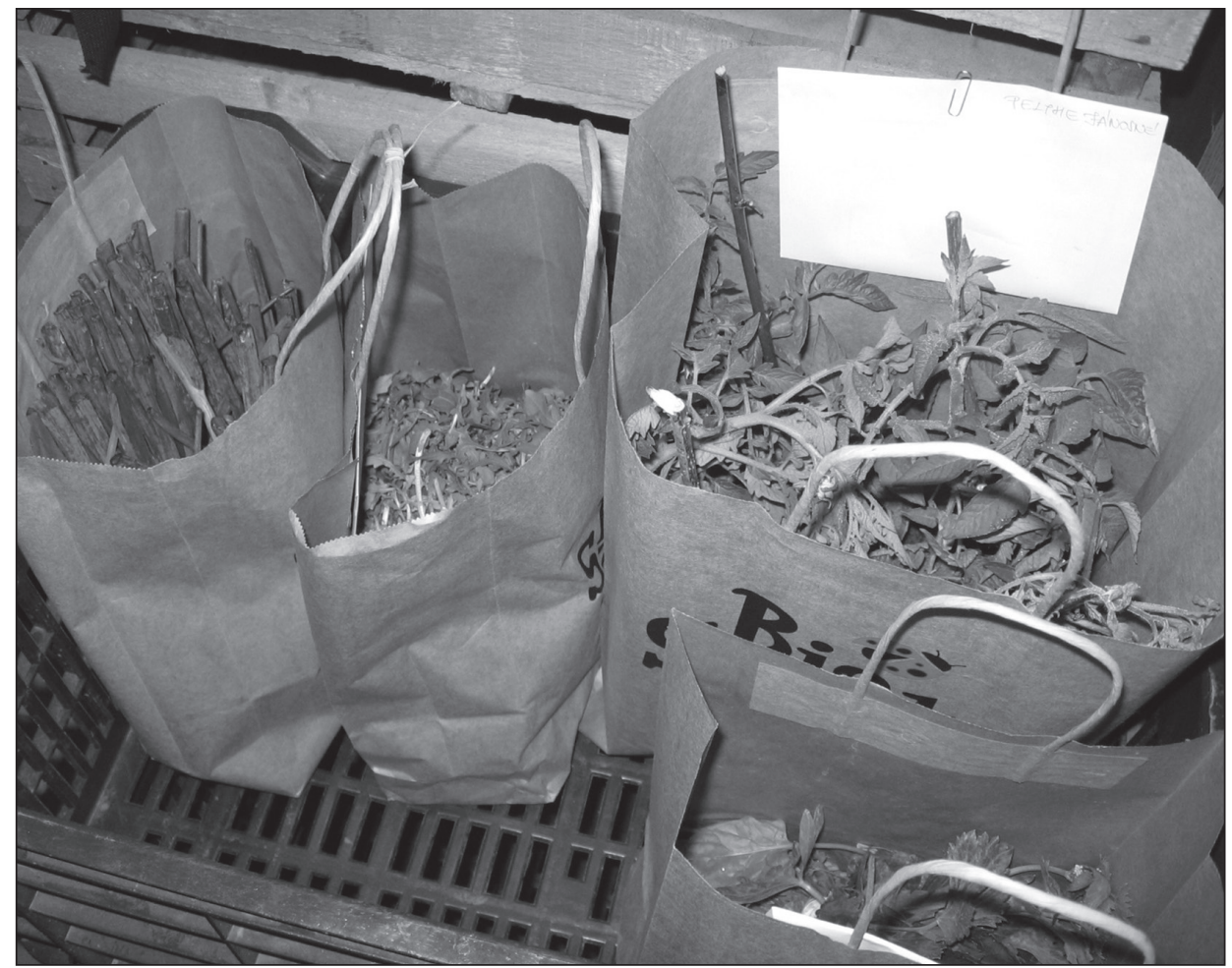

Figure 3. Fresh, weighed, packaged vegetables and herbs. Hernádszentandrás, Hungary, 2016. (Photo by Anikó Báti)

The annual order and structure of crop production are significantly different from the earlier peasant traditions; in this case, it is the constantly changing market demands that determine the pace of planting. This survey and market research are the responsibility of the sales manager. She is negotiating with the buyers, planning next year's production 


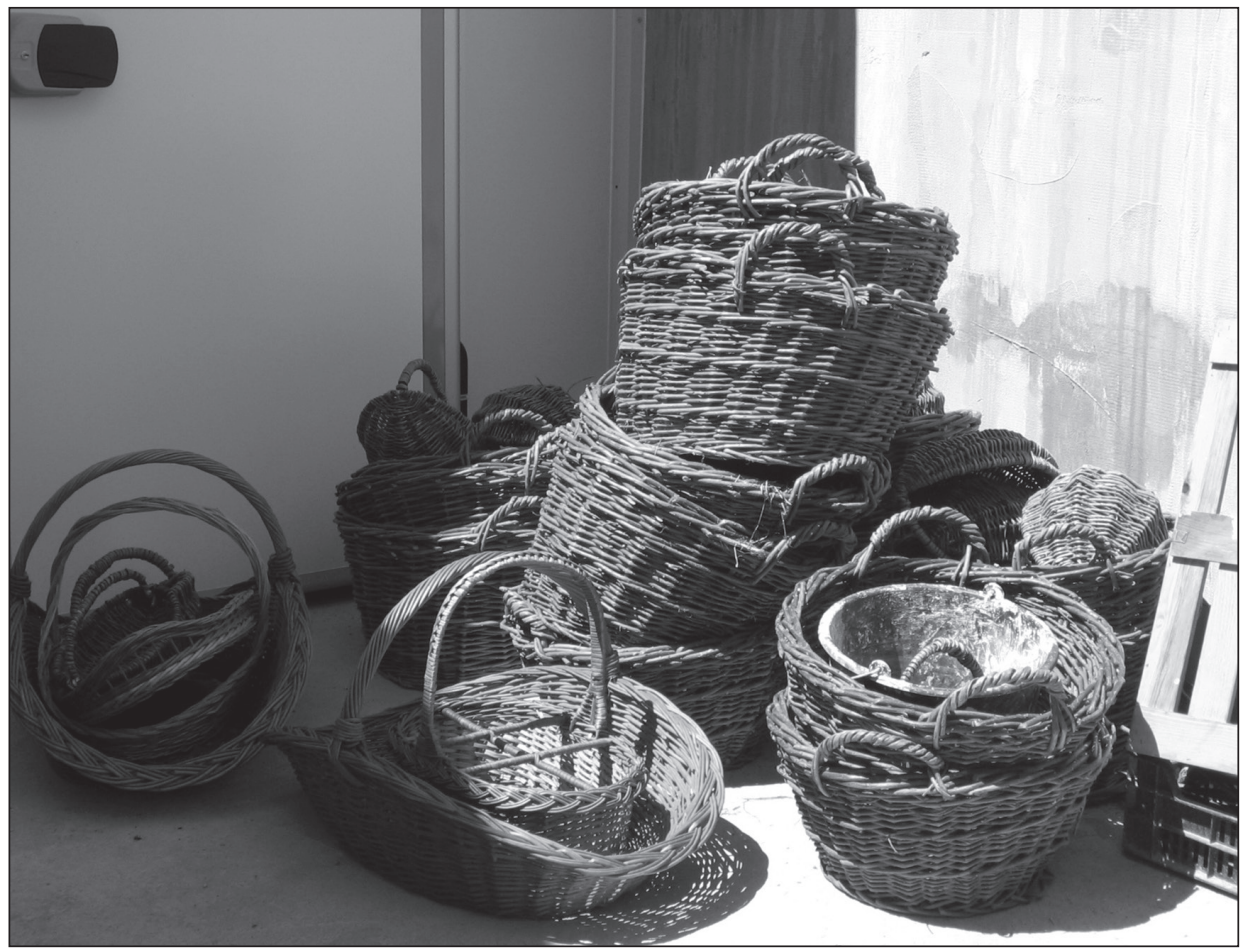

Figure 4. Handcrafted, locally produced wicker baskets in which products are offered at fairs. Hernádszentandrás, Hungary, 2016. (Photo by Anikó Báti)

schedule and the crops grown based on their needs. Approx. $70 \%$ of the yield is sold through their regular partners, but they have many casual customers, too, and sell products through their webshop as well. By 2016, the bio-farm became the permanent supplier for four restaurants, two of which are in the category of fine dining! Their demand is the decisive measure of the level of production and sales. The highest quality goods from the bio-farm are also their trademark goods, which they need throughout the year, occasionally overriding the cyclical nature of production. The scheduling of works in the garden is largely determined by their needs. For example, in the place of the spring onion pulled from the ground, they will immediately plant the next one, to keep it in stock. The 30 kinds of herbs and many types of leafy lettuce are also primarily there to meet their needs. Farm workers and villagers did not even know much of them, never having had used them before.

In September 2015, a well-equipped, modern processing plant and bio-kitchen were also built, and named the "Taste House". By selling products made from vegetables and fruits processed here, they will be able to finance the paychecks throughout the year. To build the processing plant, the 140-year-old building of the former school was modernized from the inside. Some of the employees had worked in horticulture before, but after completing further training, they took on the job, which was a great advancement for them, and of which they are very proud. With modern machines, 10-12 products such as marmalades are made, but there is also a 10-cell solar-powered food dehydrator. For 


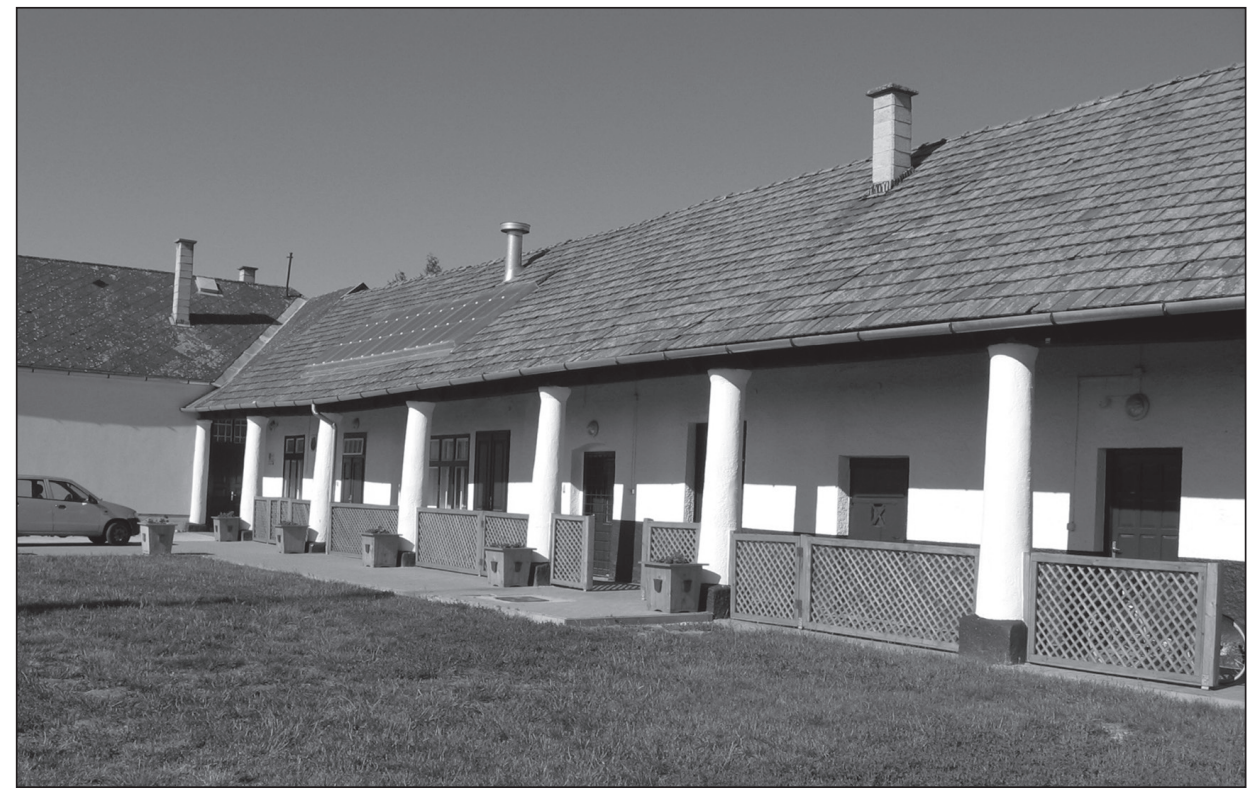

Figure 5. "Taste House" processing plant in the 140-year-old building of the former school. Hernádszentandrás, Hungary, 2016. (Photo by Anikó Báti)

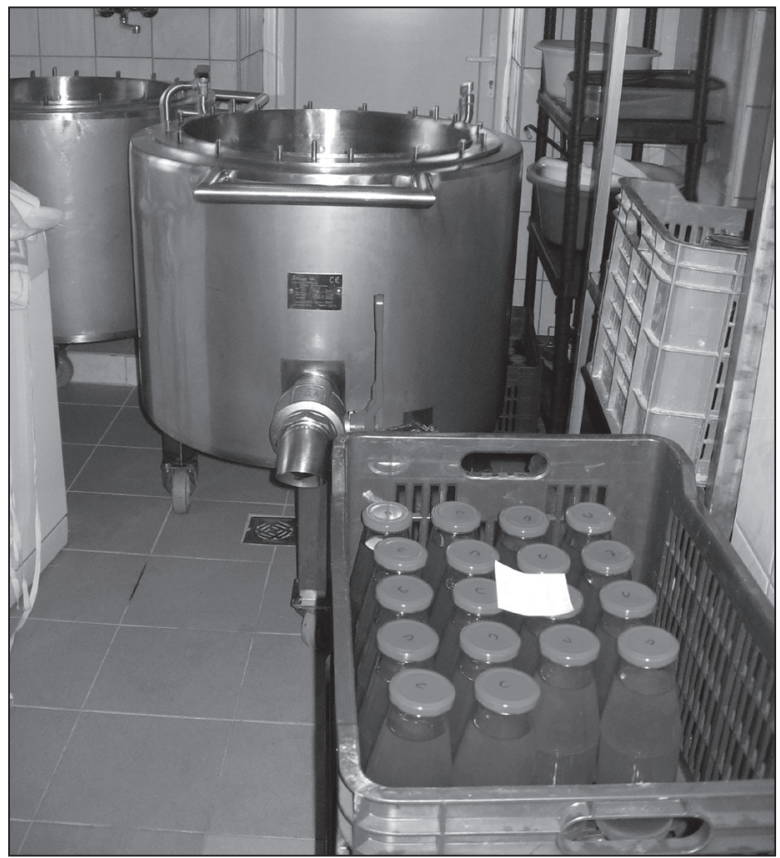

Figure 6. "Taste House" is a processing plant with stateof-the-art technology. Hernádszentandrás, Hungary, 2016. (Photo by Anikó Báti) 
example, they make ketchup, eggplant and onion chutney, pickles, jam from rose-hips harvested in the forest. The latter became a popular commodity through the revival of old peasant traditions and practices. Recipes have been developed collectively, incorporating the ideas of the workers. They are constantly experimenting with flavors and products. For example, thinking of people with diabetes, they try to use stevia [Stevia rebaudiana] as a sweetener instead of sugar. This plant is still a novelty in Hungary. It has come to the bio-farm, among the cultivated plants, as a part of health-conscious nutrition. Among the participants in the program, some have family members living with severe diabetes, so they know the dietary problems of those with the disease, and they suggested using it. Stevia can be a solution for them as a natural sweetener. They are working on recipes with food engineers so that this new plant could be included in their processed products as well. They do not use preservatives in the processing plant; the process and method of cooking is much like peasant cooking. At the same time, however, they all work very precisely, using the latest kitchen technology.

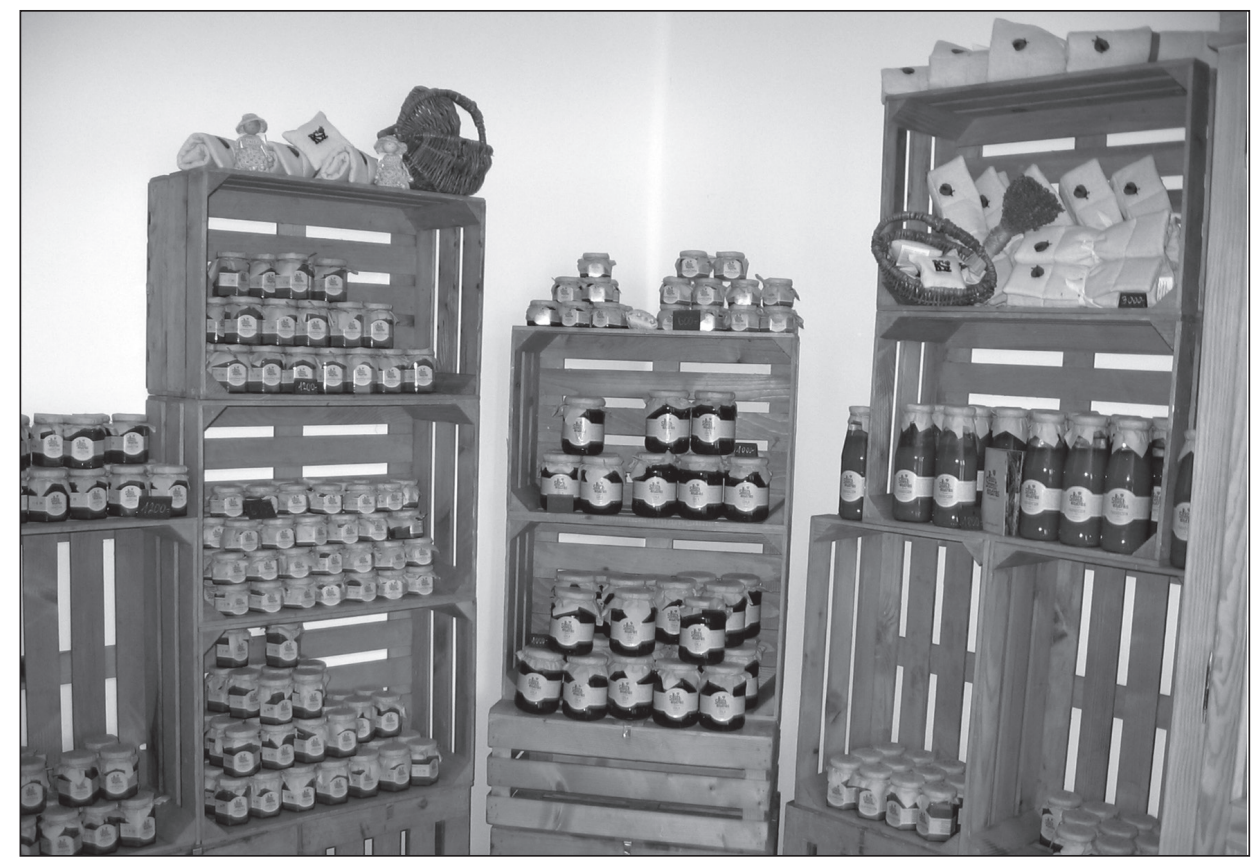

Figure 7. A wide range of products from "Taste House" in the showroom. Hernádszentandrás, Hungary, 2016. (Photo by Anikó Báti)

Thinking of BioSzentandrás and with the leadership of the mayor and the sales manager, they are trying to design the local economic development as a complex system. Besides the production of garden vegetables, they would like to enter the wider market with higher-priced goods sellable all year round, to create their own brand, and to ensure the continuous operation of the processing plant by organizing the small-scale farmers of the surrounding small villages as external suppliers. The building of commercial networks and partnerships has also been successful, as not only their fresh vegetables and herbs but 
also other products are sold in more and more places, locally and in surrounding big cities, even in Košice in Slovakia. The success of the project has made the settlement attractive to businesses. When I was there, during my fieldwork in 2016, a private contractor was just beginning to set up a vegetable and fruit processing plant targeting international markets, in collaboration with the BioSzentandrás project. All this will mean more jobs and more opportunities for farmers to sell. Such developments are not only profitable for economic reasons, they also contribute to preserving local values, traditions, and farming patterns, strengthening identity, and even generating tourist attraction (KABAI - NÉMETH 2012).

\section{NEW MATERIALS ON THE TABLE}

In the households of the examined group, the range of raw materials used was expanded with salads and herbs. Greater emphasis is placed on health-conscious nutrition - the impact of mass communication is clearly demonstrated here - but at least as important is the fact that they do not have to spend money on their chemical-free vegetables and fruits. Thus, living expenses can be significantly reduced. Their motives, therefore, are not primarily influenced by a conscious consumer behavior, a resistance to a globalized food market - as could be presumed based on the literature. A complete exploration of recent changes in food culture and consumption patterns would exceed the planned scope of this study, and further, targeted fieldwork is still needed. Let me simply address the topic of raw materials used. Another topic to be considered in the future is whether the pursuit of self-sufficiency as a practice can become more common beyond the circle of those involved in organic gardening.

All project participants cultivate their backyard garden, some even have a plastic tunnel, and the pursuit of self-sufficiency is becoming increasingly important in their life strategy. This activity gained momentum with the opening of the bio-farm; although many people used to cultivate their land, the use of organic gardening methods was less conscious. It should be noted, however, that all this, as a reduction of expenditure, is not the strategy of the most disadvantaged families within the village.

Many of the new types of vegetables and herbs discovered in the bio-garden have appeared in the food culture of the examined community as well. Employees of the processing plant are at the forefront of incorporating innovations. They are the ones who have learned not only the production of raw materials but also their uses, so they have the utmost insight into the processes. Everyone also utilizes the theoretical and practical skills learned in the seminars at home, such as using their home-grown ingredients to make, together, ketchup and jam according to the new recipes.

They strive to innovate within familiar, known frameworks and recipes so that new elements can be integrated into the eating habits of the family and thus be more easily accepted. For example, from the stem of the Swiss chard, it is also possible to make a favorite dish of Hungarian cuisine, pörkölt [stew], which is served with gnocchi or boiled potatoes, just like the meat version. In the families studied, the older men were the most hesitant, while the children and the young women were delighted with the innovations. Getting to know a wide range of garden vegetables, the menu was expanded in Hernádszentandrás with a new element in the Hungarian food culture: fresh salad. The circle has been expanded with the addition of arugula, Swiss chard, etc., which are novelties next to the long-known lettuce 
but feature on the menus of restaurants. Never before have they tasted mizuma salad, or various sprouts, even spinach was unknown. They were surprised at the fact that what they knew as weeds, ${ }^{12}$ others consumed as salads. These ingredients are clearly, consciously considered as part of a healthy diet. Salads have become alternatives to high carbohydrate garnishes, pastas and potato dishes. This conscious approach and taste change reflects primarily the impact of the bio-farm's supply, which is well suited to the aspirations of healthy nutrition that are present in the public consciousness but less common in practice.

After the change of regime, in Hernádszentandrás a clear and significant decline in living standards and changes in consumption patterns can be documented at the level of food culture. ${ }^{13}$ With the abolition of the agricultural cooperative, the opportunity to get cheap, high-quality feed for their animals was eliminated, which was part of the annual allowance of the cooperative's workers. This change has led to a decline in animal husbandry at the level of individual households. It was no longer efficient to keep animals, as it was cheaper to get the meat from the store. Today there are hardly any pigs, geese, ducks, and many do not even keep laying hens, they just buy eggs from the store. There are some who get a fattened pig from the neighboring town - where the cooperative survived after the reorganization - and slaughter it and process it at home. Many people buy fresh milk from that same village as well. The shops of nearby cities offer fresh red and white meats, eggs at any time, reliably accessible, pushing the pursuit of self-sufficiency into the background.

However, the bio-farm has an inspirational effect on animal husbandry, too. The tiers that were built on each other in traditional peasant economies, plant cultivation and animal husbandry, still complement each other in the present. In addition to cultivating a garden around the house, many have also revived animal husbandry, incorporating garden wastes into the feed. It is also a sign of health-consciousness, because they consider the quality of meat important - as opposed to commercially available goods. Some of the new herbs (thyme, rosemary, lovage, tarragon, coriander) are, in fact, not new at all, their use has just receded in the past 50-60 years, but now, having gained a new momentum, they are enjoying a renaissance in the Hungarian kitchen, complemented by the flavorings of Mediterranean cuisine. The workers take them home from the bio-farm to try them out:

\footnotetext{
"They ask why it is like this. I say, because I put that spice on it. Mostly they accept it, or say it was delicious but don't do it again." "The new spices are best with fried meat." "I put the oregano in the tomato dish, the two kids absolutely did not eat it. So I'm doing it without it, the traditional way, so that everyone would eat it." (Three employees of the "All that" house, interviewed by Anikó Báti, 2016.)
}

With the new spices, new recipes and cooking methods have also appeared. Such a method not used so far is, for example, marinating meat before baking, which is also a healthier way of preparing meals.

"There are new recipes. There are things in which I would not have put [green spices] before, but now I would not leave them out. Herbs for roasted meats. It used to be only ground pepper.

\footnotetext{
${ }^{12}$ For example, pigweed [Amaranthus Retroflexus].

${ }^{13}$ For changes in consumer seed harvest on a national level, see: TöRőCsIK 2012.
} 
Now these, if you have to marinate. These herbs are indispensable for that. We did not even used to marinate the meat." (Worker at the "All that" house, interviewed by Anikó Báti, 2016.)

Home-made syrups could be healthier alternatives to soft drinks, and their novel ingredients also come from the bio-farm. They make syrup from lemongrass, mint, lavender. These drinks show up at the programs and demonstrations organized by the village and the bio-farm, and they are met with great cheer.

Within the studied group, several people make home-made compote from cherries, apricots or plums, even the ones who do not work at the processing plant. The latter group stressed, however, that they are still following the practices of earlier decades, although they have heard about the innovations at the plant: they continue to use preservatives, and for thickeners they use mainly sugar and not the apple pectin used at the plant.

\section{THE BIO-FARM IS MORE THAN A FARM}

The gates of the bio-farm are open to both buyers and visitors. They seek to introduce the concept they represent, the importance of a health-conscious lifestyle, to as many people as possible. They organize "planting, gardening days", BioSzentandrás activities for families and school groups, where they can gain insight into the basics of chemical-free farming, get acquainted with new plants and flavors. The program also includes a guided tour of flavors, not just for external guests, during which they can get acquainted with the vegetables in the bio-garden, the products of the processing plant, which tomatoes are good for what, for example; but the organizers themselves also learn, because the guests offer up good ideas and opinions about recipe or product development as well.

The accepting, open spirit represented by the project, and the community-building role of the initiative are very well illustrated by the fact that on these "planting days" healthy and disabled children can work together in the garden, getting to know each other, helping each other. The garden is also a permanent supplier to a restaurant in the nearby metropolis which is operated by people with disabilities.

As for the future, their goal is to expand the range of goods they produce, the number of neighboring farmers they associate with as suppliers, as well as the number of shops involved in their sales. They would also like to further develop the range of services related to the bio-farm, such as taking advantage of the opportunities afforded by the popularity of gastro-tourism. The production, processing and sales system has now been fully developed. The local government will try to minimize its coordinating role in the future, once the business is fully operational on a market basis.

The BioSzentandrás project extends far beyond chemical-free farming. The village as a whole started to develop, too, the infrastructure was significantly renewed: piped water was introduced, canal and telephone networks were built, and there are not many neglected, uncultivated yards anymore. The project is of utmost importance not only from the perspective of local economic development and job creation - it could also be the key to the future of the village's community, too. An initiative that serves as an example for the villages of the region. It was the aspects of community building, thinking in systems, and sustainable development that made it stand out in a line of similar initiatives. In 2013, the BioSzentandrás project brought Hernádszentandrás a "Prix Territoria - Dévelopement 
Local" innovation award for which nearly 500 settlements were in the running. And in 2015, in the "European Social Innovation Competition" launched by the European Investment Bank, the BioSzentandrás project was selected from 350 entrants to be among the final 16.

The sales manager formulated the secret of their success in the following way:

\begin{abstract}
"Perhaps the key to the system is that those who are here represent a human value. We appreciate those who are here. It's very hard to work in a system where we cannot afford to pay yet, but our goal is to make enough sales to pay everyone's wages for their work. (...) People can see that the goods are selling. And they are surprised that, Good God, we have sold so much again! The buyer comes, pays in cash, and pays for more than one month's wages. This is a great value. They know that what they create, what they are working for is valuable. (...) It moves me forward to see growth. For example, when we go to a product demonstration, I'll bring the feedback back to [the employees]." (Sales manager, interviewed by Anikó Báti, 2016.)
\end{abstract}

The consumption of traditional, local products and foods is one of the most significant food trends in Hungary and worldwide (LysaGHT 2017). The project fits in with the new developmental direction in which sustainable agricultural production also serves to preserve and build the local community. "...small businesses and family farms are usually more diversified and less environmentally detrimental, employ gentler technology, build more on local knowledge, their specific energy demand is less, they depend less on global networks, and last but not least, they employ proportionately more people than their size" (KAJNER et al. 2013:11). These include the communally cultivated gardens of housing complexes, or the eco-villages. ${ }^{14}$ Producer and consumer communities, produce markets (KISBÁN 2017a, 2017b) are being built between cities and their agglomerations based on the personal relationship between the producer and the buyer, the commitment to ecological sustainability, and the opposition and objection to the global commodity supply of supermarkets.

\title{
REFERENCES CITED
}

AGÓRA

$2016 \mathrm{http}: /$ infocracy.hu/eloadasok/bemutatkozik-bioszentandras/ (accessed July 1, 2016) AszTALos Morell, Ildikó

2015 Social Farming as a Means of Poverty Reduction in Rural Hungary DoI: 10.18030/socio.hu.2015en.83 (accessed August 1, 2016)

BÁTI, Anikó

2017 Organic Farm: A Chance for Renewal. (An Example from North-Eastern Hungary). In Bartsch, Silke - Lysaght, Patricia (eds) Places of Food Production. Origin, Identity, Imagination. $21^{\text {st }}$ International Ethnological Food Research Conference in Heidelberg, forthcoming publication.

\footnotetext{
${ }^{14}$ See, e.g.: Farkas, Judit: „Nincsenek receptek”. A magyar ökofalvak táplálkozásantropológiai vizsgálata ["There are no recipes". Nutrition Anthropological Survey of Hungarian Eco-Villages], http://tabula. neprajz.hu/neprajz.07.16a.php?bm $=1 \&$ as $=418 \& \mathrm{kr}=\mathrm{A} \_10 \_\% 3 \mathrm{D} \% 222015 \% 2016 \% 281-2 \% 29 \% 22$ (accessed August 1, 2016.); and the papers of Gergö Hajba, Judit Farkas in the current volume.
} 
BiOSZENTANDRÁS

$2016 \mathrm{http}: / / w w w . b i o s z e n t a n d r a s . h u(a c c e s s e d ~ A u g u s t ~ 1,2016)$

BROWN, Lester R.

1981 Building a Sustainable Society. New York: W. W. Northon and Company.

CsETE, László - LÁNG, István

2005 A fenntartható agrárgazdaság és vidékfejlesztés [Sustainable Agricultural and Rural Development]. Budapest: MTA Társadalomkutató Központ.

Csurgó, Bernadett - MegYesi, Boldizsár

2015 Local Food Production and Local Identity: Interdependency of Development Tools and Results. DoI: 10.18030/socio.hu.2015en.167 (accessed August 1, 2016)

HANN, Chris

1980 Tázlár, a Village in Hungary. Cambridge: Cambridge University Press.

1983 Progress toward Collectivised Agriculture in Tázlár, 1948-1978. In Hollos, Marida - MadAY, Bela (eds) New Hungarian Peasants. An East-Central European Experience with Collectivization, 69-92. New York: Brooklyn College Press. East European Monographs 134.

HERNÁDSZENTANDRÁS

2016 http:// www.hernadszentandras.hu (accessed August 1, 2016)

KABAI, Gergely - NÉMETH, Nándor

2012 A vidéki munkahelyteremtés régi-új útjai. Szociális szövetkezetek és falugazdaságok mintaprogramjai [Old and New Ways of Establishing Workplaces. Pilot Projects of Social Cooperatives and Rural Farms]. FonyódKeszthely: Vidékfejlesztési Minisztérium - NAVKI.

KAJNER, Péter - LÁNYI, András - TAKÁCs SÁNTA, András (eds)

2013 A fenntarthatóság felé való átmenet jó példái Magyarországon [Good Examples of Transition to Sustainability in Hungary]. Budapest. http:// humanokologia.tatk.elte.hu/wp-content/uploads/a_fenntarthatosag_fele.pdf (accessed September 20, 2016)

KisBáN, Eszter

1995 Economics of Shortage: Conditions of the Food 'Market' in the Case of Hungary. In P. DEN Hartog, Adel (ed) Food Technology, Science and Marketing. European Diet in the Twentieth Century, 168-186. Edinburgh: Tuckwell Press.

2017a Termelök a piacon, termelöi piacok [Farmers on the Market, Farmers' Markets]. In Fodor, Péter - Gyöngyösi, Orsolya (eds) Sodrásban, 298-311. Csongrád: Csongrádi Információs Központ - Csemegi Károly Könyvtár - Tari László Múzeum.

2017b Choose Local, Try Organic, Think Ecological - Actions and Ideas in the Recent Hungarian Food Realm. In LYSAGHT, Patricia (ed) Places of Food Production. Origin, Identity, Imagination. $21^{\text {st }}$ International Ethnological Food Research Conference in Heidelberg, forthcoming publication.

Lovas KIss, Antal

2002 Farming Attitudes in Transition. Ethnographica et Folkloristica Carpathica 12-13:347-362. 
2013 Factors Influencing the Change in Farming Activity in the South Bihar Region since the Regime Change of 1989. Acta Ethnographica Hungarica 58(1) 149 162.

LYSAGHT, Patricia (ed)

2017 Places of Food Production. Origin, Identity, Imagination. $21^{\text {st }}$ International Ethnological Food Research Conference in Heidelberg, forthcoming publication.

SÁRKÁNY, Mihály

2005a Re-study of Varsány: Entrepreneurs and Property in Rural Hungary after 1989. In SKaLnIK, Peter (ed) Anthropology of Europe: Teaching and Research, 143151. Prague: Set Out. Prague Studies in Sociocultural Anthropology 3.

2005b Studies on Changing Rural Social Structure in Hungary in the Second Half of the $20^{\text {th }}$ Century. In KiLianova, Gabriela - KöstuIn, Konrad - Nikitsch, Herbert (eds) Ethnology in Slovakia at the Beginning of the $21^{\text {st }}$ Century. Reflections and Trends. Proceedings of the International Conference Dedicated to the $55^{\text {th }}$ Jubilee of the Institute of Ethnology of the Slovak Academy of Sciences, 148157. Bratislava-Wien: Ustav etnologie SAV/UB.

SÁRKÁNY, Mihály - HANN, Chris

2003 The Great Transformation in Rural Hungary: Property, Life Strategies and Living Standards. In Hann, Chris (ed) The Postsocialist Agrarian Question. Halle Studies in the Anthropology of Eurasia, 117-141. Münster: LIT Verlag.

TöRöCsIK, Mária

2012 Szociális lecsúszás és fogyasztás [Social Backsliding and Consumption]. http://www.trendinspiracio.hu/tanulmanyok/szocialis_lecsuszas-kutatasmelyinterjuk_alapjan.pdf (accessed July 18, 2013)

ÜvegEs, Gábor (ed)

2012 ${ }^{(2)}$ Hernádszentandrás monográfíja [Monograph of Hernádszentandrás]. Miskolc: Németh Nyomda Kft.

VALUCH, Tibor

2005 From Long House to Squares. Changing Village Living Conditions in Sixties Hungary. In RaINer, M. János - PÉTERI, György (eds) Muddling Through in the Long 1960s: Ideas and Everyday Life in High Politics and the Lower Classes of Communist Hungary, 135-159. Budapest: Trondheim-Institute for the History of the 1956 Hungarian Revolution - Program on East European Cultures and Societies. Studies On East European Cultures and Societies 16.

See biography of Anikó Báti at the end of guest editors' foreword: Organic Farm, Organic Food. Steps Towards a Sustainable Agriculture (with Hungarian and Slovenian Examples), at page 275 . 
